\title{
Raposas e outsiders no futebol paranaense: um estudo sobre relações de poder e genealogia de Luiz Demétrio Janz Laibida1.
}

\author{
Natália Cristina Granato²
}

- Enviado em 21.09.2016

- Aprovado em 17.10.2016

Recém defendida no Programa de Pós-Graduação em Sociologia da Universidade Federal do Paraná, a tese de doutorado de Luiz Demétrio Janz Laibida possui uma importante contribuição para os estudos que envolvem a relação entre o poder político-econômico e a estrutura genealógica de famílias que reproduzem a sua dominação no âmbito do poder local, em amplas esferas socioculturais, entre elas a futebolística, objeto central no qual o autor se debruça em sua pesquisa. A tese relaciona-se com a produção do Núcleo de Estudos Paranaenses, coordenado pelo Professor Ricardo Costa de Oliveira, orientador da tese, e a biografia pessoal do autor, interessado pelo futebol paranaense e suas redes de poder ao longo de sua trajetória acadêmica.

No capítulo 1, intitulado "Enquadramento teórico e revisão bibliográfica", o autor problematiza os instrumentos teóricas das Ciências Sociais para entender as relações de poder político e econômico dentro do campo do futebol paranaense. Utilizando-se das contribuições de Pierre Bourdieu e seus conceitos de campo e capitais, articulando-os com o seu objeto, o autor também estabelece diálogo com os estudos do seu orientador, o Professor

\footnotetext{
${ }^{1}$ LAIBIDA, Luiz Demétrio Janz. Raposas e outsiders no futebol paranaense: um estudo sobre relações de poder e genealogia. Tese. Doutorado em Sociologia. Orientador: Prof. Dr. Ricardo Costa de Oliveira. Curitiba, Universidade Federal do Paraná, 2016. Disponível na integra http://acervodigital.ufpr.br/handle/1884/43058. Acesso 21.set.2016.

2 Mestra em Sociologia pela Universidade Federal do Paraná. Bacharela e Licenciada em Ciências Sociais pela Universidade Federal do Paraná. Endereço eletrônico: nataliagranato@hotmail.com
} 
Ricardo Costa de Oliveira, no que se refere ao estudo das genealogias e das classes dominantes no Paraná, organizadas em famílias, além do antropólogo Roberto DaMatta e suas reflexões sobre o futebol e a cultura brasileira, além de Karl Manheim e suas reflexões sobre o conceito de geração, e Halbwhachs e seu conceito de memória. 0 autor também destaca teóricos marxistas e os conceitos de classe dominante, luta de classes, hegemonia e ideologia para Karl Marx, Antônio Gramsci e Louis Althusser.

O capítulo 2, intitulado "As raposas e os outsiders do nosso futebol: dimensões sociológicas, históricas e socioculturais”, o autor enfoca os traços biográficos dos dirigentes do futebol em Curitiba, problematizando quem são os "dominantes” (ou raposas), tradicionais figuras da política paranaense, e os "dominados" (outsiders) neste campo, que se inseriram no mesmo através de barganhas e acesso às instituições da classe dominante, contando com acúmulos de capitais intelectuais e econômicos. Do levantamento estatístico realizado pelo autor a partir da análise posopográfica dos presidentes dos clubes, o autor enfatiza que aproximadamente 65\% deles são “outsiders" e 35\% são "raposas" (p.57). A partir daí, há um histórico do surgimento dos clubes de futebol no Paraná no início do século XX.

No capítulo 3, intitulado "Os Donos da Bola: Federação Paranaense de Futebol, os clubes de futebol profissional da capital e os clubes pioneiros no futebol paranaense", o objetivo principal é a apresentação da estruturação e composição da Federação Paranaense de Futebol e seus clubes: Coritiba Football Club, Clube Atlético Paranaense, Savóia Futebol Clube (Água Verde), Britânia Sport Club, Palestra Itália, Clube Atlético Ferroviário, Colorado Esporte Clube, Pinheiros Esporte Clube, Paraná Clube, JMalucelli Futebol SA e Pioneiros Futebol Clube. Apresentando a história de cada um destes clubes, o autor relaciona o seu material empírico com a teoria de Norbert Elias e o seu conceito de configuração e Erving Goffman e o seu conceito de representação.

O capítulo 4, intitulado "Futebol e globalização: revisitando as raposas e outsiders" dedica-se a problematizar a relação entre o futebol da contemporaneidade e o processo de globalização, que gerou a gestão do futebol com uma lógica empresarial. Como conclusões, o autor apresenta que o futebol paranaense é dominado em grande parte pelas famílias que se perpetuam nas esferas de poder político e econômico ao longo de gerações e se modificou com o tempo, do "amadorismo" à profissionalização e elitização. 
Para os leitores e pesquisadores que se interessam pelo futebol paranaense em suas perspectivas sociológicas, a tese é recomendada, a mesma conta com materiais históricos e grande diálogo entre teorias que ajudam a entender o campo social futebolístico. 